\title{
neofilolog
}

\author{
Czasopismo Polskiego Towarzystwa Neofilologicznego \\ ISSN 1429-2173, 2019, NR 52/2, 313-333 \\ http://dx.doi.org/10.14746/n.2019.52.2.8 \\ http://poltowneo.org/
}

Hadrian Lankiewcz

University of Gdańsk

https://orcid.org/0000-0001-5124-7861

hadrian.lankiewicz@ug.edu.pl

Emilia Wq̨sikiewicz-Firlej

Adam Mickiewicz University, Poznań

https://orcid.org/0000-0003-4457-9715

emiliawf@amu.edu.pl

\section{THEORETICAL CONSIDERATIONS FOR DEVELOPING INTERCULTURAL SENSITIVITY THROUGH TRANSLATION ACTIVITIES: BEYOND THE MONOLINGUAL PREMISE IN FOREIGN LANGUAGE EDUCATION}

\begin{abstract}
The article presents theoretical considerations pertaining to the use of translation in foreign language teaching and argues for the reinstatement of translation activities in language teaching to contribute to the development of intercultural sensitivity among language users. The authors build upon criticalecological reflections in language education. They posit that a globalized world requires a departure from the monolingual language teaching paradigm, particularly in multicultural and multilingual contexts such as, for example, a united Europe. The argument touches upon the issues of neoliberal skills training, intercultural education, language pedagogy (glottodidactics), language acquisition and translation theories as well as observations of the practicalities imposed on L2 users by the postmodern reality and market forces. The authors present the incorporation of translation practices into foreign language teaching as a means of enhancing intercultural sensitivity and a way of fighting linguistic and cultural colonization. The ultimate goal the new "paradigm shift" (Butzkamm and Caldwell, 2009) - is to contribute to social justice via foreign language education.
\end{abstract}


Keywords: translation, foreign language education, language skills, intercultural sensitivity

Słowa kluczowe: tłumaczenie, nauczanie języka obcego, sprawności językowe, wrażliwość interkulturowa

\section{Introduction}

The authors intend to present the theoretical foundations for perceiving translation as one of the key skills for bilinguals and plurilinguals. Such a view contrasts with traditional understandings of language skills in language teaching literature, such as speaking, reading, writing and listening. Capitalizing on the concepts of multi-competence (V.J. Cook, 1991) and the tenet of social justice through foreign language education (e.g. Lankiewicz, 2015), as well as recent calls for the reinstatement of translation in language teaching (TILT) (e.g. Butzkamm and Caldwell 2009; G. Cook, 2010), we offer a reconceptualization of the function of translating and interpreting in the process of language learning and language use for people who function within more than one language system. Subsequently, assuming a sociocultural constitution of language learning, as defined by Lantolf (2000), we posit that interlingual translation activities may contribute to the growth of intercultural sensitivity. The bridging platform for this line of thinking is drawn from Kramsch's contribution to the perception of the place of culture and language teaching (1993) and the application of the ecological metaphor to language learning (2002, 2012) as well as the concept of cultural grammars by Wierzbicka (1996). Valuable insights for developing intercultural sensitivity via translation are also derived from the concept of the third culture (Damen, 1987), third place (Kramsch, 1993) or tertiary socialization (Byram, 1989).

Such an attitude stands in contrast to the dominant monolingual vision of language as documented in language teaching methodology books and language teaching manuals, promoting the monolingual development of four skills (listening, speaking, reading and writing; cf. Malmkjær, 1998: 5), as it is the case in the still dominant communicative approach. Inherent incompatibilities between languages require the application of translation techniques by bi- and plurilinguals ${ }^{1}$ in the communication of meanings as they are allowed by a particular language system and manifested by a particular culture.

\footnotetext{
${ }^{1}$ Assuming the ecolinguistic metaphor in language learning and capitalizing on SLA research pertaining to the abolishment of the dichotomy language learner/ language
} 
It is in the translation process, be it only mental (characteristic of language processing - e.g. intercomprehension in translingual practices, cf. Mazak and Carroll, 2017), or exteriorized (spoken or written) that intercultural differences are made more visible in the language system itself. In the process of language learning the said dichotomy may be construed in relation to receptive and productive skills. Ultimately, we perceive translation, after Susan Bassnett (1998: $\mathrm{xx})$, as "the performative aspect of intercultural communication" and posit the incorporation of translation as a constitutive skill for a foreign language learner/user and a way of developing their language awareness level.

\section{Translation and language teaching}

Language teaching methodology in the communicative era, triggered by the functional approach to language study, articulates four basic language skills within the receptive (reading and listening) and productive (writing and speaking) continuum. This well-grounded taxonomy may be perceived as inadequate, and provides an additional proof of the monolingual conceptualization of foreign/second language learning discussed widely in modern language teaching literature in the context of bi- and plurilingualism (Malmkjær, 1998). Accordingly, Todeva and Cenoz (2009) claim that second language acquisition (SLA) has neglected prior or simultaneous language learning experience and instead focused either on linguistic and communicative competence in the target language, students' interlanguages influenced by L1 interferences, or on "the cognitive outcome of being proficient in both languages" (2009: 3). This shortsighted perception of SLA is unanimously referred to as a "monolingual bias" (cf. Grosjean, 1985; Block, 2003; Pavlenko, 2005). Eventually, as Todeva and Cenoz point out, L2 skills have "typically been judged by strict native speaker norms and have invariably been found lacking" (2009: 3).

Criticism of the monolingual bias may be made on different grounds, as will be manifested in the latter part of the article. Temporarily, limiting our considerations to language skills, we posit that the focus on four language skills in foreign language teaching methodology constitutes a blatant example of bias. The existence of the skills seems to be derived from a structural analysis of native speaker competence, or the psycholinguistic understanding of L1 acquisition. Language teaching methodologists have even gone so far as to recommend a progression from listening to speaking, reading, and writing in

user (cf. Kramsch (ed.), 2002; Firth and Wagner, 1997), we consider any communicative knowledge of language in addition to one's mother tongue respectively as bi- or multilingualism. 
developing them, to mirror the natural process of $\mathrm{L} 1$ acquisition. This was a consequence of equating L1 and L2 acquisition as similar processes. Hence, regardless of age, Krashen and Terrell, proponents of naturalistic language acquisition in their Natural Approach (presented in 1983) to language learning, accentuated the importance of the development of listening comprehension in pre-speech in the form of comprehensible input without "having to respond in the target language" (1995: 76). Speaking was supposed to develop as a result of a stress-free classroom atmosphere and subsequently fostered by properly organized instruction. Reading and writing activities were to come later. Similarly, earlier methods such as the Direct Method and its more scientifically grounded European Oral Approach (cf. Richards and Rodgers, 2001: 31) were informed by the empirical observations of the native speaker. The monolingual bias is also inscribed in the tenet that the language of instruction should be exclusively the target one.

The above-mentioned teaching methodology, proposed as a remedy for the Grammar- Translation Method and being a corollary of Chomskyan mentalism "colonizing" linguistics, did not allow space for translation activities. The functional approach to language learning and teaching, triggered by the concept of communicative competence, has been basically distrustful towards an incorporation of translation activities into language teaching (Savignon, 1983: 47).The desire to acquire the target language underscored the concept of appropriacy and authenticity as the parameters for the learner's language competence. Translation activities, in this perspective, were unwelcome, since they might have facilitated transfer from the learner's mother tongue, which was not perceived of as capital for building genuine personal meanings, or as a way of developing linguistic or cultural awareness.

Nonetheless, translation was considered an integral part of language teaching for decades within the Grammar-Translation Method, alternatively referred to as the Prussian Method in the United States, due to the German origins of its exponents (cf. Richards and Rodgers, 2001: 3). In short, its advocates assumed $L 1$ to be a reference point for acquiring $L 2$, thus the grammar system and lexis of the known language became a point of reference for the learning of the new one. Ultimately, grammar items were the main organizational hubs within the syllabus. Both grammar and accompanying vocabulary were presented in reference to mother tongue equivalents, or approximations if one-to-one correspondence was difficult to find. With the focus on developing receptive skills, particularly preparing students to read original foreign language texts, this way of teaching dominated much of the history of language teaching and became referred to as classical or traditional, and was severely criticized by the majority of "well-informed" theoretical methodologists and practitioners, lamenting the still common use of translation activities 
by some teachers. Consequently, this marriage of translation and language teaching, as Munday (2016: 14) posits, has negatively influenced translation in general as a type of linguistic activity, and for a long time "academia considered it of a secondary status" and the "[s]tudy of the work in translation was generally frowned upon once the student had acquired the necessary skills to read the original" (ibid.).

Much of the criticism of translation within the paradigm of formal linguistics is justified. It needs to be underscored here that linguistically driven concepts of equivalence were restricted to the level of the sentence in translation theories and have, in a sense, been detrimental to Translation Studies. Translation techniques derived from the Grammar-Translation Method were form- rather than meaningoriented and lacked full semantic, pragmatic and intercultural validity and were taught in the contextual vacuum. The controversial issue was the assumption that different language systems can be effectively compared with each other and similarities or differences (equivalents) identified (cf. Newmark 1981: 52).

Consequently, the sentence-oriented structural linguistics continued by Comparative Linguistics, featured in language teaching in the form of the Contrastive Analysis Hypothesis, and in Translation Studies inspired equivalence theories. The concept of equivalence was initially triggered within the Russian school of linguistics and it looked for one-to-one correspondence, while the French school searched for an equal functional value and ultimately laid the foundations for the concept of dynamic equivalence. The two different strains of equivalence theories "argue that translation is possible despite cultural or grammatical differences between SL[source language] and TL [target language]" (Panou, 2013: 2). On the other hand, they "both recognize the fact that the role of the translator should not be neglected and acknowledge some limitations of the linguistic approach, thus allowing the translator also to rely on other procedures that will ensure a more effective and comprehensive rendering of the ST [source text] message in the target text" (ibid.).

This approach to language teaching has been criticized by developments in linguistics offering post-structural visions of language (functional or interactional theories of language), developments in SLA allowing for a new understanding of how language functions and how the process of language learning works. An additional impetus for accentuating productive skills has been undoubtedly enhanced by the communication of the postmodern world with the predominant characteristics of oracy (Fairclough, 1992: 33) or secondary orality, as maintained by Ong (1982), who claims we are seeing the "technologizing of the word" via the mass media dominating the construction of our reality (Jameson, 1991: xiii).

The orality of the era of late capitalism has been reflected in the socalled Communicative Approach, encompassing a wide spectrum of practices 
(cf. Richards and Rodgers, 2001: 64ff.). The new language teaching practice "stressed students' natural capacity to learn language and attempts to replicate 'authentic' language-learning conditions in the classroom. It often privileged spoken over written forms, at least initially, and generally avoided use of the students' mother tongue. This led to the abandoning of translation in language learning" (Munday, 2016: 14).

With the articulation of translation studies as a separate field of language studies by James Holmes (1972/ 1988), in his seminal paper presented at the conference in Copenhagen in 1972, and the communicative turn in language teaching, academics representing foreign philology departments naturally presumed that translation as a skill should be restricted to professional courses. It became considered an extra ability, outside the repertoire of language skills characteristic of a person possessing a practical knowledge of at least two linguistic systems. The strong version of the Communicative Approach, which could be characterized by the slogan "using English to learn" (Howatt, 1984: 279; after Richards and Rodgers, 2001: 66), assumed that knowledge of the language does not necessarily entail knowledge about the language (KAL), as Language Awareness has primarily been defined (cf. Andrews, 2008: 289). Therefore, it was believed that $L 2$ learners are not able to carry out interlingual translation due to the incommensurability of the two linguistic systems, which actually might have been the case (cf. Lankiewicz, 2015: 133-195 for the criticism of the Communicative Approach in the context of Language Awareness). Additionally, research in SLA focused around the notion of interlanguage fostered the conviction promoting the separation of translation from the four basic language skills.

Only recently, in the aftermath of the "sociolinguistic revolution" (Johnson, 2008: 56) and the emergence of the sociocultural approach to language study and language learning (Lantolf, 2000; van Lier, 2004), have voices declaring the value of translation in language learning been heard again. One of them is G. Cook (2010), who in his ground-breaking book argues that "translating should be a major aim and means of language learning" (p. xv) and he presents the reasons for relegating translation from language teaching techniques, a process which has been initiated by the so-called Reform Movement at the end of the $19^{\text {th }}$ and continued through the $20^{\text {th }}$ century and caused by, as Munday (2016: 14) posits, "the attempts to replicate 'authentic' languagelearning conditions in the classroom". G. Cook (2010) articulates basic pedagogical, cognitive and practical misconceptions regarding the withdrawal of interlingual translation techniques from pedagogical practices, such as the fact that translation is a boring classroom activity, it does not facilitate L2 acquisition or the claim that students do not need it in the real world. He also 
maintains that some decisions regarding the withdrawal form the incorporation of translation into language teaching were of a political and commercial character (related to neoliberal policies). Hence, he argues, that there reason were totally external to academic reflections pertaining to language processing or language acquisition and ultimately promoting exclusively monolingual language teaching. Eventually, the author calls for the reassessment of translation practices during foreign language education, pointing to the interdisciplinary character of translation and its formative place in language teaching. We may add that, alternatively, language teaching is equally formative for professional translation processes as such.

The critical turn in Language Awareness, as initiated by Fairclough (1992), necessitated a general revision of non-critical language use in language pedagogies. Significant in this regard is the problematizing of the common sense concept of language appropriacy (Fairclough, 1992: 35-56), which eventually led to questioning of the dominant $20^{\text {th }}$ century approach of Communicative Language Teaching (CLT), which effaced the latent learning potential in translating activities.

More contemporary academics delving into the language learning process highlight different assets of language activities based on translation. Wach (2017) presents interlingual translation as a grammar learning strategy for bilinguals. She evokes other scholars who postulate that reliance on learners' L1 benefits them regarding the development of their language awareness and sensitivity (Gozdawa-Gołębiowski, 2003) or provides them with confidence that they understood the relation between the meaning and form of particular grammar structures (Brooks-Lewis, 2009; Littlewood and Yu, 2011). Vermes (2010), in turn, revises basic negative reflections regarding translation practices in the educational milieu by providing sound counterarguments. He eventually concludes that "[ $t$ ]he objections to the use of translation in foreign language teaching are all based on a limited view of translation. But translation is not only structure manipulation; it is primarily a form of communication" (p. 91).

\section{Translation as a constitutive skill for bi- and plurilinguals}

As foreshadowed before, the value of TILT may be re-considered with reference to the monolingual bias dominating "fashionable high-profile language teaching" (G. Cook, 2010: xv) as opposed to socio- and psycholinguistic reality of bi- and plurilinguals.

Kramsch (2012), in one of her lectures, mentioned, in an anecdotal way, that the domains of research in second language acquisition and bilingualism seem worlds apart, manifested by two different metaphorical concepts of the 
language learner and the language user respectively, as highlighted by Firth and Wagner (1997). The divide is unfounded for the fuzziness of the two notions in real life situations. Capitalizing on her considerations and allowing for the transition from bilingualism to plurilingualism characteristic of modern times, particularly in the European context (cf. Widła, 2016), we extend Kramsch's sociocultural or ecolinguistic perspective to our context.

Vermes (2010), considering the use of translation in the field of foreign language teaching, concludes that there are no fundamental reasons for the exclusion of translation from language education. He elaboratively quotes and comments on the voices against the use of TILT. The objections, as he interprets them, derive from a "limited view of translation" (p. 91). By this, he means that the opponents of translating activities in language teaching basically perceive it as the process of transferring phrases or sentences in a word-for-word manner from one language to another, exactly the same way as it was practiced in the infamous Grammar-Translation Method. Keeping in mind the reflection on formal equivalence (Nida, 1964: 158 in Munday, 2001: 42), the disadvantages articulated against the efficiency of translation activities in a language class are basically unfounded and methodologically biased, e.g. some of them pertain only to written translation, or that restricted to the sentence level. In other words, all criticism referring to translation is modeled by "the kind of translation that was practiced in foreign language classroom" (Vermes, 2010: 88) rather than by socio- and psycholinguistic processes underlying language learning.

The monolingual language learning bias has led to the belief that translation, being psycholinguistically more complex, is independent of the four skills and is available only to people who have already mastered the new language system. Yet Vermes (2010: 88) cites opinions of other scholars demonstrating that translation is based inevitably on the practice of the four basic skills (Malmkjær, 1998: 8). It needs also to be stressed that cognitive theories (e.g. Fodor, 1983 or Anderson, 1992) "describe the processes of speaking, listening, reading and writing as all relying on a form of mental translation" (Vermes, 2010: 88).

Equally unfounded seems to be argument, regarding the unnatural nature of translation. A simple observation of bi- and plurilingual people in their natural milieu allows us to gain substantial evidence to show that translation is a frequent strategy, or an expected form of linguistic activity. Similarly, language learners use translation in their learning processes irrespective of teacher expectations or classroom practices. However, for some students it may be a key strategy for language learning, depending on the language learning attitude (cf. Wilczyńska, 2002). Research on language acquisition allows the claim that translation is "a latent component of language competence" (Lengyel and Navracsics, 1996: 60; after Vermes, 2010: 89) and it facilitates the language acquisition process. Ultimately, Vermes 
(2010: 88) refers again to Malmkjær (1998: 8) "that there is no reason why we should not regard translation as a natural skill in its own right and why it could not be used as a natural classroom activity".

An important argument for considering translation as a natural skill for bi- and plurilinguals may be derived from V.J. Cook's concept of multicompetence (1991: 112), which is "the compound state of a mind with two grammars" or "the knowledge of more than one language in the same mind" (V.J. Cook 2002: 10). The concept of multi-competence highlights the problem of measuring the success of an L2 learner against the characteristics of a native speaker, which was a result of describing an L2 user in terms of an L1 user. V.J. Cook postulates that $L 2$ users "are indeed unique users of language in their own right" (V.J. Cook 2005: 50). In his concept, interlanguage is understood in a verbatim way as an "integration continuum" (V.J. Cook, 2002), affecting all language systems in the possession of a person, as well as the whole brain. By this, he opts for a bilingual perspective in understanding the process of language learning and language use in general. The coexistence of two or more systems in one mind has been extended to the characteristic property of multilingual communities (cf. Nakagawa, 2017: 186). The redefinition of multicompetence was to account for the totality of linguistic knowledge and corresponding cognitive restructuring triggered by linguistic means. V.J. Cook (2005: 51-53), articulating the fundamental differences between monolinguals and bilinguals, refers to the confirmatory effects of $L 2$ on the minds of language users. He mentions, among others, issues related to raised language awareness as well as a cognitive recategorization of basic linguistic concepts.

The concept of multi-competence capitalizes on the basic premise that L2 learners are at the same time L2 users, for example, outside school. Legitimization of the learner as an L1 user leads V.J. Cook $(1999,2002)$ to debunk the native speaker myth of a competent language user as a frame of reference for measuring success in $\mathrm{L} 2$ acquisition.

Correspondingly, the division between pedagogical vs. real translation (Klaudy, 2003: 133; after Vermes, 2010: 83), and school translation vs. professional translation (Gile, 1995: 22; after Vermes, 2010: 84) may reflect the same problem. The underlying distinction consists in seeing it either a tool or as a goal. The fuzziness of the distinction between the two types of translation in actuality echoes the problem of differentiating between language learner and user. Vermes (2010: 84 ) recognizes the ambiguity in the use of this terminology since, as he points out, even profession translation training is not translation proper, and suggests calling this type of translation simulated translation. The inherent dilemma of the suggested taxonomies is the assumption that even a professional translator, similarly to any L1 language user, 
will always remain a learner. The translation products of trained and licensed translators offer clues to their linguistic and intercultural competences in the same way as those of pedagogical or simulated ones. This is not to say that professional translation training is groundless, it is rather to claim that all types of translations are real and natural, they simply may be used for different purposes. It is also important to keep in mind that translation as such should be also considered as an inherent skill of all bi- and plurilinguals, and made use of in the process of $L 2$ learning for the benefit of increasing linguistic and intercultural competence.

Thereby, bi- and plurilinguals, apart from cognitive differences, "employ a wider range of language functions than a monolingual for all the needs of their lives. An L2 user can be seen in terms of métissage [original emphasis] 'the mixing of two ethnic groups, forming a third ethnicity'" (V.J. Cook, 2005: 51). They simultaneously use more than one language via translation, code switching, or practices of translingualism (Canagarajah, 2013; Mazak and Carroll, 2017). Additionally, research both on natural and instructed SLA indicates that language learners are naturally engaged in repertoire of translation activities Malakoff and Hakuta (1991), they may contribute markedly to the understanding and intake of comprehensible input (Sheen 1993). Thereby, pedagogical reliance on four skills in second language learning and teaching may not facilitate natural processes (of which translation is an integrative part) in which language learners engage.

To sum up, there is no reason why translation should not be used in the language classroom, particularly in the case when students share the same L1 with the teacher. It is only important to remember that translation activities should not "lead to treating the meanings of the second language as translation equivalents of the first language" (V.J. Cook, 2005: 59). Code-switching and translation should be treated as an inevitable occurrence in bi- and multilingual contexts, for various reasons ranging from language processing to sociocultural reality. All L2 users engage in some sort of "natural" translations as mediators (V.J. Cook, 2002: 5), and we dare say this ability should be taken for granted, since it is expected from bi- and plurilingual language users in various moments of their lives. One way of incorporating translating activities into the language learning process is increasing $\mathrm{L} 2$ users intercultural awareness and sensitivity.

\section{Translation as an intercultural activity}

The shift in defining multi-competence, signaled by Nakagawa (2017), is essential for our considerations, since it echoes the theory of linguistic relativism (interrelated connections between language, culture and thinking). In this 
respect, Dewaele (2016) argues that "while the multicompetence perspective focuses on the effect of the new language rather than the new culture on the mind of the speaker, it is in fact quite difficult to separate these two entwined variables" (p. 463; after Nakagawa, 2017: 189). Nonetheless, relying on cognitive research carried out on bi- and plurilinguals (cf. Murahata, 2010; Murahata and Murahata, 2007; Athanasopoulos, 2001), we posit that "language cannot be separated from the rest of the mind or the community, but rather language influences the cognitive dispositions of $\mathrm{L} 2$ users including cultural and social aspects" (Nakagawa, 2017: 191).

Framing translation within intercultural communication is not a completely new idea. Steiner (1975) has a pioneering role in this, by claiming that "inside or between languages, human communication equals translation" ( $p$. 47). In the book After Babel, he conceptualizes communication as a form of translation and visualizes it as an important component for intercultural relations. As he argues, it is impossible to carry over complete meanings from one culture to another and the translation act is always tinged with the translator's culture. Katan (2009) comments on translation in this ethnocentric bias. Starting from Bennett's statement (1998: 3) that "cultures are different in their languages, behaviour patterns, and values. So an attempt to use [monocultural] self as a predictor of shared assumptions and responses to messages is unlikely to work", Katan posits the function of a translator as a cultural mediator. He ultimately claims that the source text itself does not offer all the cues and the target text "will be read according to a different map or model of the world, through a series of different set of perception filters" (Katan, 2009: 91).

To consider translating activities as a means of raising intercultural awareness in the process of foreign language learning, it is important to see it as an intercultural communication activity, rather than mental gymnastics to see the formal differences in the grammar system of compared languages (traditional pedagogical use of translations). It should focus on sociocultural meanings derived from structural differences, which constitute a cultural memory. Schäffner (2003), stressing the overlap between translation studies and intercultural communication manifested by, for example, conference titles, calls for an integrated approach, possibly with Translation Studies as a sub-discipline of Intercultural Communication Studies (p. 102). Yet despite the common thematic concerns, the two disciplines are not well-informed regarding their research findings and, surprisingly, the understanding of translation in Intercultural Communication is restricted basically to a linguistic phenomenon (Witte 2000: 95), which, as Schäffner (2003: 101) maintains, may be ascribed to the fact that both disciplines are still methodologically insecure (each fighting for a discipline in its own right) not to lose its "genuine object of research" (p. 86). 
The history of translation theories ironically evidences the basic shift from the category of formal equivalence, faithful replicas of source texts, to the perception of translation as a purpose-oriented activity demanding some text manipulation. Due to space limitations, suffice it to say that the so-called "cultural turn" in Translation Studies introduced by Bassnett and Lefevere's volume Translation, History and Culture (1990) still holds sway in the discipline with a more critical twist initiated by Tymoczko and Genzler (2002) presented in the volume titled Translation and Power.

Translation largely constitutes an asymmetrical cultural exchange, with the active role of translators shaping the intercultural exchange, as well as being shaped themselves by socio-political practice they represent (Venuti, 1995). Therefore, similarly to a bi- and plurilingual language user, the translator performs the role of intercultural mediator and it can be maintained that contemporary Translation Studies focus "on social, cultural, and communicative practices" (Schäffner, 2003: 86) and underscore the value of the visibility (agency) of the translator. This acting and interacting is characteristic of both Translation Studies and Intercultural Communication since, as Schäffner (2003) posits, they "operate on the basis of shared assumptions" (p. 90).

Undoubtedly, translation is a form of interhuman communication, and Translation Studies draw heavily on communication research, particularly discourse-oriented approaches of the 1990s, as well as other communication-oriented models of translation (cf. Munday, 2001/2016). What is essential, however, is the fact that human communication needs some cultural filtering in the form of contextualizing, framing or logical typing (Katan, 2009: 76ff). Intercultural Studies, and Intercultural Communication in particular, offer a framework for the recognition of cultural differences in any translation act, be it natural or pedagogical translation (cf. Vermes 2010), if the division should be maintained at all.

\section{Raising intercultural sensitivity through translation activities in the process of language learning}

As mentioned before, the narrow understating of translation in foreign language education resulted in a totally biased approach to the use of translation activities in the learning process. The redefinition of translation from the universalist perspective of encoding-decoding, typical of those who perceive language and culture as separate entities and assume a "conduit metaphor of language transference" (Munday, 2001: 75) to the intercultural perspective, fully restores its educational value as well as helps reconceptualize translating as a constitutive skill for bi- and plurilingual language users. While monolinguals function competently within four skills, those who operate within two 
or more linguistic systems are subject to linguistic and cultural overlapping (not to use the misleading term of interference) in the communication act.

Language learning is the place of convergence for the processes of translation and intercultural communication (an inherent feature), since any language use is never culture free. Language switching inevitably entails mediation of cultural issues, some of which are inscribed in the structure of the language itself, while others are context-bound. This is equally true for unicentral languages (one language-one culture) and pluricentral languages (one language many cultures) such as English, and particularly English as a Lingua Franca. Intercultural communication never pertains to relations between equals, and L2 use is a political act, reflecting power relations between the cultures of the interlocutors, as well as cultural grammars (Wierzbicka, 1996: 527).

The teaching of culture has long been a crucial issue in language teaching, particularly accentuated by the functional approach to language teaching. Similarly, functionalists raised culture-related issues in translation studies, converging in this way with problems of intercultural communication. Briefly, it can be summarized by the claim that the target text should be markedly different from the source text in order to fulfil the cultural norms in which it is to function. This leads to an assumption that it is possible to produce a text which conforms with the criteria of target culture. Schäffner (2003) argues that such a perspective has produced the effect that "issues of difference, power, resistance, hybridity, etc. - key notions in postmodern theories - [were] hardly addressed in a forceful way" (p. 90). In other words, more contemporary translation theories underscore the fact that cultural equivalents necessitate adaptation techniques, thereby adaptation is a constitutive part of translation.

The culture related-concerns articulated in the field of Translation Studies reverberate with Fairclough (1992), who has criticized the notion of appropriacy in language teaching. The alleged existence of culturally binding norms in language learning, as he argues, has led to the naturalization of language (uncritical use of clichés, which do the thinking for people) and the celebration of native speaker norms in foreign language teaching. Thus, narrow-minded and uncritical functionalism was equally detrimental to translation and language teaching.

The critical (postmodern) turn in both fields brought about a marked difference to the place of cultural issues in language learning and translation theories, as proposed by Venutti (1995), in the strategies of domestication and foreignization. Subsequently, it resulted in the prominence of intercultural studies, whose ultimate objective is not enculturation, but rather an understanding that the other (foreign culture) and the self (native culture) are inherently related. In other words, the balanced construction of the self necessitates the presence of the other, as has been stipulated by Bakhtin (cf. 
Hermans, 2001 for the application of his theory to cultural positioning). Therefore, the intersection for the areas considered in this paper (translation, language teaching in the era of plurilingualism and intercultural communication) is the concept of the third culture (Damen, 1987), third place (Kramsch, 1993) or tertiary socialization (Byram, 1989), understood as a reflective observation of cultures in contact from a position of distance.

Developing intercultural sensitivity through the reinstatement of translation activities in language teaching may be perceived as a way of fighting linguistic colonialism (Canagarajah, 1999). In the era of globalization, language is no longer in the possession of the native speaker. The call for Lingua Franca English (Canagarajah 2007), as opposed to English as a Lingua Franca, is significant here. It is unfair to presume that $L 2$ users would be equally competent. They offer a legitimate voice as language users (Lankiewicz, WąsikiewiczFirlej and Szczepaniak-Kozak, 2016). In reality, they are more competent in certain respects (for example, being able to translate and mediate cultures).

TILT may also be perceived as a critical argument in a neoliberal language teaching policy (Lankiewicz, 2018). The principal tenet of a neoliberal education policy is commercialization, but ironically language teaching still celebrates naïve monolingual communicative orality, while globalized communication necessitates translation on the part of bi- and plurilingual language users. This is an observable phenomenon of authentic intercultural communication both at home and in public places. It may also be inferred from "[e]mployment opportunities based on a knowledge of English [...] likely to demand an ability to mediate between English and another language, not only to communicate in monolingual English contexts" (G. Cook, 2017: 739).

Assuming power issues in the process of translation, the fact that language learning is a personal experience (van Lier, 2004) and applying the tenets of the critical approach to intercultural communication (Byram, 2012), we posit that translation activities may raise the intercultural awareness of language learners, make them more sensitive users of language, and better citizens, in the sense of being aware of sociocultural issues inscribed in language and ready to respond to them in an active way (Lankiewicz, 2015). Correspondingly, G. Cook (2010), delineating the strong argument for TILT, oscillating around the declarative knowledge of language and culture awareness issues, sees it as a positive force in strengthening language acquisition, but also as an academic inquiry which "can promote critical thinking and serve as a bulwark against manipulation and deception" (p. 122-3). Thus, academically driven knowledge is perceived as a remedy for uniformed translations causing problems in the real world. Random, de-contextualized translation of same unstable of culturally laden terms might cause real-life problems (Pym, 2013). 
The fulcrum in our considerations is the recognition of translation as an integral part of language learning with professional translation being a natural extension of it, and resulting from former experiences. It should not be treated as an additional activity, but as a means for developing metalinguistic awareness, which Karpińska-Musiał (2015) postulates as being of key importance in shaping perlocutionary responsibility in communication. In this perspective, the intercultural competence of a language learner, based on metacognitive awareness, is surely not the same as translation specific (inter)cultural competence (Witte, 2000: 163; after Schäffner, 2003: 93), yet it allows for cross-cultural understanding via aware language use (Karpińska-Musiał, 2015: 114). G. Cook (2010) accordingly criticizes the complacent view "of intercultural contacts as unfailingly benign" ( $p$. 119). This basic assumption of intercultural communication needs reconceptualization in the context of ubiquitous hate speech (Kozak and Lankiewicz, 2017:1356). In this regard, G. Cook, evoking Thomas (1998), considers translation as "provoking disagreement and conflict laying bare the differences between languages and cultures" (p. 119). Thus metalinguistic knowledge is to help escape "form the prison of language and culture" (ibid.) and demonstrates the incompatible worlds views of many of the speakers of two languages involved" (ibid.). Research on hate speech, mentioned above, may indicate that globalization and internationalization processes do not easily root out personal, cultural stereotypes. Indeed, they may occasionally result in schizophrenic attitudes: a private and public face.

We can think of a large number of exercises which might be incorporated into foreign language teaching, derived directly from the translation practice of "culturemes" (Katan, 2009: 79) - terms functioning only in one of the cultures. Making students aware of translation strategies applied in the rendition of culturally-embedded phenomena (Kwieciński, 2001: 157) in the commonly accepted terminology, or asking them to transfer, for example, some songs laden with culturally specific issues, may be a good occasion for raising intercultural sensitivity inscribed in language. Such an activity would target metacognitive language awareness pertaining to the surface level of culture in Hall's diagram (1959/1990) with language being only one conspicuous aspect.

On a deeper level of the cultural iceberg, Katan (2009), evoking other translation scholars, describes translation practices pertaining to allusions which are more context-based and require "the extralinguistic knowledge of the source language culture" (p. 81). In this respect, comparison of some proverbs or fixed expressions might offer students some insights into different lifestyles, customs and rituals, which can be observed only in the form of cultural abstractions. Relying on the mechanical memorization of traditional equivalents impedes cognitive processes which might lead to developing deeper layers of language awareness and arouse issues pertaining to cultural relativism. 
However, the very core of intercultural communication refers to the level of basic assumptions - the levels of values and beliefs. These are things which cannot be identified in texts in a verbatim way. One needs to read between the lines to get the picture of an emergent different world. In translation proper, it boils down to the problem that the conduit metaphor of rendition would not be able to offer the same message without mediation. These inconsistencies are dubbed cultural grammars. Wierzbicka (1996: 527; after Katan, 2009: 86) describes this concept as "a set of subconscious rules that shape a people's ways of thinking, feeling, speaking, and interacting".

Space limitations stop us from a more detailed presentation of the way of sensitizing students to culturally-bound language use via translating. Moreover, on this level it is even difficult to offer a formal guide to follow. To discover the representation of reality inscribed in language use one has to apply, for example, the analytical instruments of critical discourse analysis to see through the words or grammar, so that language, as Allport (1986) puts it, is not set of linguistic clichés or "labels of primary potency" - indiscriminate uses of language doing the thinking for people. Meanings are not only communicated by single words, but also by culture-specific or individual rhetoric reflecting underlying values and ideologies. One possible activity might be the exercise of analyzing a student's own or somebody else's rendition of a text to make the translator visible (Venuti, 1995) through words, expressions or grammar. In other words, any text, the same as its translations, always reflects the author's sociocultural affiliations and ideological mindset. In more general terms, any text is a signature of humanity marked by personal activity (thinking through language).

Foreign language learning is part of the construction of citizenship, as admitted by some national curricula (cf. G. Cook, 2010: 108), while international communication is just a necessity of a globalized world, a remarkable part of which is done through translation. Hence, it is odd to separate the three components if foreign language teaching is to meet the accountability principles set by neoliberal education polices (cf. Lankiewicz, 2018).

\section{Conclusion}

Translation can be a powerful instrument in raising L2 learners/users linguistic and intercultural awareness, it is only necessary to depart from the narrowminded understanding of what it entails. It is, in a sense, ironic that Translation Studies a long time ago discarded the concept of formal equivalence, yet foreign language teaching practices applying translation mainly as a way of testing, adhere to the traditional approach. This is where G. Cook's (2010: 122) argument against the fallacy that academic knowledge has no relation to practical skills, 
assumed by the proponents of communicative methodologies, is blatantly true. In other words, should language teaching be more informed by Translation Studies regarding linguistic means, there would certainly be a rationale for translation activities during language classes in modern language teaching methodology, or at least they would be of a different kind.

The reality of a globalized world, supported by theoretical considerations pertaining to human linguistic activity, does not leave room for dissociating newly acquired languages from the mother tongue. Translation in this regard should be an treated as an constitutive skill for bi- and plurilingual language users and, if properly used, might serve a purpose in enhancing intercultural communication by more discriminate, more informed language use, marked by perlocutionary responsibility. In the long term, an awareness of intercultural issues inscribed in language targets social justice.

\section{REFERENCES}

Allport, G. 1986. "The language of prejudice" (w) Language awareness (red. P. Escholz i in.). New York: St. Martin's Press: 261-270.

Anderson, M. 1992. Intelligence and Development: A Cognitive Theory. Oxford: Blackwell.

Andrews, S.J. 2008. "Teacher Language awareness" (w) Encyclopedia of Language and Education, $2^{\text {nd }}$ Edition, volume 6: Knowledge about Language. Springer Science+Business Media LLC: 287-298.

Athanasopoulos, P. 2001. L2 acquisition and bilingual conceptual structure. MA thesis, University of Essex.

Bassnett, S. 1998. "Preface" (w) Constructing cultures: Essays on literary translation. (red. S. Bassnett i A. Lefevere. Clevedon: Multilingual Matters: vii- xxii. Bassnett, S. i Lefevere, A (red.). 1990. Translation, history and culture. London: Pinter Bassnett, S. i Lefevere, A. 1998. Constructing cultures: Essays on literary transIation. Clevedon: Multilingual Matters.

Bennett, M.J. 1998. "Intercultural communication: a current perspective" (w) Basic Concepts of Intercultural Communication: Selected readings (red. M. J. Bennett), Yarmouth, ME: Intercultural Press Inc.: 1-34.

Block, D. 2003. The social turn in second language acquisition. Washington, D.C.: Georgetown University Press.

Brooks-Lewis, K. A. 2009. "Adult learners' perceptions of the incorporation of their L1 in foreign language teaching and learning". Applied Linguistics, 30: 216-235.

Butzkamm, W i Caldwell, J. 2009. The bilingual reform: A paradigm shift in foreign language teaching. Tübingen: Narr Studienbücher. 
Byram, M. 1989. "Intercultural education and foreign language teaching". World Studies Journal 7(2): 4-7.

Byram, M. 2012. "Language awareness and (critical) cultural awareness - relationships, comparisons and contrasts". Language Awareness, 21(1-2): 5-13.

Canagarajah, A. S. 1999. Resisting linguistic imperialism in English teaching. Oxford: Oxford University Press.

Canagarajah, S. 2007. "The ecology of global English". International Multilingual Research Journal 1(2): 89-100.

Canagarajah, S. 2013. Translingual Practice. Global Englishes and cosmopolitan relations. New York: Routledge.

Cook, G. 2010. Translation in language teaching: An Argument for Reassessment. Oxford, Oxford University Press.

Cook, G. 2017. "Translation and language teaching" (w) The Routledge encyclopedia of language teaching and learning (red. M. Byram i A. Hu). New York: Routledge, 737-740.

Cook, V. J. 1999. Going beyond the native speaker in language teaching. TESOL Quarterly 33, 2: 185-209.

Cook, V.J. 1991. "The poverty-of-the-stimulus argument and multi-competence". Second Language Research, 7, 2: 103-117.

Cook, V.J. 2002. "Background to the L2 user" (w) Portraits of the L2 user (red. V.J. Cook). Clevedon: Multilingual Matters Ltd.: 1-28.

Cook, V.J. 2005. "Basing teaching on the L2 user" (w) Non-Native Language Teachers Perceptions, Challenges and Contributions to the Profession (red. E. Llurda). New York: Springer: 47-62.

Damen, L. 1987. Culture Learning: The fifth dimension in the language classroom. Reading, MA: Addison-Wesley Publishing Company.

Dewaele, J.-M. 2016. "Multi-competence and emotion". The Cambridge Handbook of Linguistic Multi-competence (red.) V. J. Cook and Li Wei, Cambridge: Cambridge University Press: 461-477.

Fairclough, $\mathrm{N}$ (red.). 1992. Critical language awareness. London and New York: Longman. Fairclough, N. 1992. "The appropriacy of appropriateness" (w) Critical language awareness (red. N. Fairclough). London and New York: Longman.

Firth, A. i Wagner, J. 1997. "On discourse, communication, and (some) fundamental concepts in SLA". Modern Language Journal 81 (3): 285-300.

Fodor, J. A. 1983. The Modularity of Mind. Cambridge, Mass.: MIT Press.

Gile, D. 1995. Basic concepts and models for interpreter and translator training. Amsterdam and Philadelphia: John Benjamins.

Gozdawa-Gołębiowski, R. 2003. Interlanguage formation: $A$ study of the triggering mechanisms. Warszawa: Instytut Anglistyki Uniwersytetu Warszawskiego. 
Theoretical considerations for developing intercultural sensitivity through...

Grosjean, F. 1985. "The bilingual as a competent by specific speaker-hearer." Journal of Multilingual and Multicultural Development 6: 467-477. Hall, E. T. 1959/1990. The silent language, New York: Doubleday

Hermans, H.J.M. 2001. "The Dialogical Self: Toward a Theory of Personal and Cultural Positioning". Culture \& Psychology 7(3): 243-281.

Holmes, James S. 1972/1988. "The Name and Nature of Translation Studies.

In Holmes, Translated! Papers on Literary Translation and Translation Studies". Amsterdam: Rodopi: 67-80.

Howatt, A.P.R. 1984. A history of English language teaching. Oxford: Oxford University Press.

Jameson, F. 1991. Postmodernism, or the cultural logic of late capitalism. New York i London: Verso.

Johnson, K. 2008. An introduction to foreign language learning and teaching [second edition]. Harlow, England: Pearson.

Karpińska-Musiał, B. 2015. Międzykulturowość w glottotydaktyce. Gdańsk: Wydawnictwo Uniwersytetu Gdańskiego.

Katan, D. 2009. "Translation as intercultural communication" (w) The Routledge companion to translation studies (red. J. Munday). London $\mathrm{i}$ New York: Routledge: 74-92.

Klaudy, K. 2003. Languages in Translation. Budapest: Scholastica.

Kramsch, C. 1993. Context and Culture in Language Teaching. Oxford: Oxford University Press.

Kramsch, C. 2012. "Authenticity and Legitimacy in Multilingual Second Language Acquisition (SLA). International Symposium across the disciplines. Multilingual 2.0." University of Arizona. April 12-15. Online: https://www.youtube.com/watch?v=VHxxpdc2PoE. [DW 28.01.2019].

Kramsch, C. 2002. Language acquisition and language socialization: Ecological perspectives. London i New York: Continuum.

Krashen, S.D and Terrell, T.D. 1995. The natural approach, Language acquisition in the classroom. London and New York: Prentice Hall McMillan.

Kwieciński. P. 2001. Disturbing Strangeness, Toruń, Poland: Wydawnictwo Edytor. Lankiewicz, H. 2015. Teacher language awareness in the ecological perspective: A collaborative inquiry based on languaging. Gdańsk: Wydawnictwo Uniwersytetu Gdańskiego.

Lankiewicz, H. 2018. "Is there a place for "sowing" in second language (L2) education at the university level? Neoliberal tenets under scrutiny" (w) Challenges of second and foreign language education in a globalized world. Studies in honor of Krystyna Droździał-Szelest (red. M. Pawlak i A. Mystkowska-Wiertelak). Cham: Springer: 197-213. 
Lankiewicz, H., Wąsikiewicz-Firlej E. i Szczepaniak-Kozak, A. 2016 "Insights into language teacher awareness with reference to the concept of self-marginalization and empowerment in the use of a foreign language". Porta Linguarum 25: 147-161.

Lantolf, J.P (red.). 2000. Sociocultural theory and second language learning. Oxford: Oxford University Press.

Lengyel, Z. i Navracsics, J. 1996. "The Ontogenesis of Translation" (w) Translation Studies in Hungary (red. K. Klaudy, J. Lambert i A. Sohár). Budapest: Scholastica: 60-68.

Littlewood, W. i Yu, B. 2011. "First language and target language in the foreign language classroom". Language Teaching, 44: 64-77.

Malakoff, M., i Hakuta, K. 1991. "Translation skill and metalinguistic awareness in bilinguals" (w) Language processing in bilingual children (red. E. Bialystok). Cambridge: Cambridge University Press: 141-165.

Malmkjær, K. (ed.) 1998. Translation and Language Teaching: Language Teaching and Translation. Manchester: St. Jerome Publishing.

Mazak, C.M. i Carroll, K.S. 2017. Translanguaging in higher education. Beyond monolingual ideologies. Bristol: Multilingual Matters.

Munday, J. 2001/2016. Introducing translation studies. Theories and applications [fourth edition]. London i New York: Routledge.

Murahata, G. 2010. "Multi-cognition in L2 users: more evidence from an object categorization task by Japanese elementary school children". Research Reports of Kochi University 59: 131-146.

Murahata, G. i Murahata, Y. 2007. "Does L2 learning influence cognition? Evidence from categorical and thematic organization of objects". Research Reports of the Department of International Studies 8: 17-27.

Nakagawa, A. 2017. "Review of multicompetence". Journal of Liberal Arts and Sciences at Tokyo City University 10: 185-194.

Newmark, P. 1981. Approaches to Translation, Oxford and New York: Pergamon.

Nida, E. A. 1964. Toward a Science of Translating. Leiden: E. J. Brill.

Ong, W. 1982. Orality and Literacy, the Technologizing of the Word. London and New York: Methuen.

Panou, D. 2013. "Equivalence in Translation Theories: A Critical Evaluation". Theory and Practice in Language Studies, Vol. 3/1: 1-6.

Pavlenko, A. 2005. Emotion and multilingualism. Cambridge: Cambridge University Press.

Pym, A. 2013. "Research skills in translation studies: What we need training in". Across Languages and Cultures, 14(1): 1-14.

Richards, J.C i Rodgers, T.S. 2001. Approaches and methods in language teaching [second edition]. Cambridge: Cambridge University Press. 
Savignon, S. 1983. Communicative Competence: Theory and Classroom Practice. Reading, Mass.: Addison-Wesley.

Schäffner, C. 2003. "Translation and intercultural communication: Similarities and differences". Studies in Communication Sciences 3/2: 79-107.

Sheen, R 1993. "An EGTM: What is it?". The Language Teacher, 17(6): 13-16. Steiner, G. 1975. After Babel. London: Routledge.

Szczepaniak-Kozak, A. i Lankiewicz. H. 2017. „Wybrane aspekty mowy nienawiści w Polsce", Lingwistyka Stosowana 21: 135-147.

Thomas, S. 1998. "Translation as intercultural conflict" (w) Languages at work (red. S. Hunstion). Clevedon: Multulingual Matters, 98-109.

Todeva, E. and Cenoz J. (2009). "Multilingualism: Emic and etic perspectives" (w) The multiple realities of multilingualism: Personal narratives and researchers' perspectives (red. E. Todeva i J. Cenoz). The Hague: Mouton de Gruyter, 1-32.

Tymoczko, M. i Gentzler, E. 2002. Translation and Power. Amherst/Boston: University of Massachusetts Press.

van Lier, L. 2004. The ecology and semiotics of language learning: a sociocultural perspective. Boston: Kluwer Academic Publishers.

Venuti, L. 1995. The translator's invisibility. London: Routledge.

Vermes, A. 2010. "Translation in foreign language teaching: A brief overview of pros and cons". Eger, Journal of English Studies, 10: 83-93.

Wach, A. 2017. "Odniesienia do języka ojczystego jako strategia uczenia się gramatyki języka obcego: perspektywa polskich uczniów języka angielskiego". Neofilolog 48/1: 73-88.

Widła, H. 2016. "Zmierzch bilingwizmu i jego skutki". Neofilolog 47/1:9-19.

Wierzbicka, A. 1996. "Japanese cultural scripts: cultural psychology and 'cultural grammar'”. Ethos, 24(3): 527-55.

Wilczyńska, W. (red.). (2002). "Podmiotowość i autonomia jako wyznaczniki osobistej kompetencji komunikacyjnej." (w) Autonomizacja w dydaktyce języków obcych. Doskonalenie w komunikacji ustnej (red. W. Wilczynska). Poznań: Wydawnictwo Naukowe UAM: 51-68.

Witte, H. 2000. Die Kulturkompetenz des Translators. Begriffliche Grundlegung und Didaktisierung, Tübingen: Stauffenburg. 